\title{
Estimation of genetic and phenotypic parameters for production traits in Holstein and Jersey from Colombia
}

\author{
Estimación de parámetros genéticos y fenotípicos para \\ características de producción en ganado Holstein y Jersey \\ Colombiano
}

\author{
Juan Rincón F, ${ }^{1,2 *}$ Ph.D, Juan Zambrano A, ${ }^{1} \mathrm{Ph} . \mathrm{D}$, Julián Echeverri, ${ }^{1} \mathrm{Ph} . \mathrm{D}$.
}

\begin{abstract}
${ }^{1}$ Universidad Nacional de Colombia. Facultad de Ciencias Agropecuarias, Departamento de producción Animal, Grupo BIOGEM: Biodiversidad y genética molecular. Calle 59 A No 63-20 B50, Medellín, Colombia. ${ }^{2}$ Universidad Tecnológica de Pereira, Facultad de Ciencias de la Salud, profesor del programa de Medicina Veterinaria y zootecnia, Carrera 27 No 10-02. *Correspondence: jcrincon@unal.edu.co
\end{abstract}

Received: September 2014; Acepted: March 2015.

\begin{abstract}
Objective. Determine the genetic and phenotypic parameters for milk yield, fat percentage, protein percentage and somatic cell score. Materials and methods. 18134 lactation records were used to Holstein and 1377 lactations for Jersey in different herds. The (co) variance components and genetic parameters were estimated using the software Multiple Trait Derivative-Free Restricted Maximum Likelihood MTDFREML. Results. The Holstein and Jersey heritability's (and standard error) for milk yield were: $0.16(0.082)$ and $0.15(0.306), 0.30(0.079)$ and $0.37(0.319)$ for protein percentage, $0.32(0.076)$ and $0.46(0.313)$ for fat percentage and for somatic cell score were: $0.01(0.054)$ and $0.01(0.233)$, respectively. The largest genetic correlations were found between the percentage of fat and percentage of protein, with values of $0.82(0.126)$ and $0.98(0.852)$ for Holstein and Jersey respectively. The lowest correlations were between fat percentage and somatic cell score with -0.01 (1.147) and -0.01 (1.734). Phenotypic correlations were generally found low and repeatability showed a significant effect of permanent environment on milk production per lactation. Conclusions. It is important to emphasize the development of research to help guide breeding programs in the tropics, using selection indices of multi-traits.
\end{abstract}

Key words: Dairy cattle, genetic correlations, heritability, phenotype (Source: AIMS).

\section{RESUMEN}

Objetivo. Determinar los parámetros genéticos y fenotípicos para producción de leche, porcentaje de grasa, porcentaje de proteína y puntaje de células somáticas. Materiales y métodos. Se utilizó información de 18134 lactancias para Holstein y 1377 para Jersey de diferentes hatos del departamento de Antioquia (Colombia). La determinación de los componentes de varianza, covarianza y los parámetros genéticos se realizó mediante el método de máxima verosimilitud restricta libre de derivadas usando el programa MTDFREML. Resultados. La heredabilidad y el error estándar en Holstein y Jersey para producción de leche fueron $0.16(0.082)$ y $0.15(0.306)$, para porcentaje de proteína $0.30(0.079)$ y $0.37(0.319)$, para el porcentaje de grasa de $0.32(0.076)$ y $0.46(0.313)$ y para el puntaje de células 
somáticas fue de $0.01(0.054)$ y $0.01(0.233)$, respectivamente. Las mayores correlaciones genéticas encontradas fueron entre porcentaje de grasa y porcentaje de proteína, con valores de $0.82(0.126)$ y $0.98(0.852)$ para Holstein y Jersey, respectivamente. La menores correlaciones fueron obtenidas entre porcentaje de grasa y puntaje de células somáticas con valores de -0.01 (1.147) y -0.01 (1.734), respectivamente. Las correlaciones fenotípicas encontradas por lo general fueron bajas y la repetibilidad evidenció un efecto importante del ambiente permanente sobre la producción de leche por lactancia. Conclusiones. El presente trabajo encuentra algunas diferencias con los reportes de parámetros genéticos en otros países, lo que resalta la importancia del desarrollo de trabajos de investigación que permitan orientar los programas de mejoramiento genético en el trópico.

Palabras clave: Correlaciones genéticas, Fenotipo, Ganado lechero, Heredabilidad (Fuente: AIMS).

\section{INTRODUCTION}

The increase in the human population has increased the need for more food derived from animal products, which creates a need to seek more efficient and productive animals from different perspectives. Some important variables in dairy milk yield can be improved by using adequate selection programs according to the specific conditions where they are performed, and precise knowledge of genetic and phenotypic parameters is critical in planning and developing adequate selection strategies (1).

Estimating genetic and phenotypic parameters is necessary to determine the degree of variation due to genetics and environment, and also to predict genetic associations between two or more variables. These parameters are commonly required to construct selection indexes and predict correlated responses and to perform more efficient genetic evaluations (2).

Animal production in Holstein and Jersey cattle requires one of the highest technical levels and they are the specialized breeds most used for milk production in the high Colombian tropics. However, estimating genetic and phenotypic parameters, and consequently genetic evaluations, have presented serious difficulties, principally due to the limited amount of periodic and trustworthy production records for characters of economic importance (3). As a consequence, selection decisions according to the needs and conditions specific to the tropics have faced great uncertainty, especially in young cows and bulls (1).

While selection of dairy cattle in Colombia has been oriented towards milk production, the variables associated with its compositional quality play a very important role in genetic selection programs due to traits that have important economic impacts for the cattle industry (4). Additionally, the somatic cell score (SCS) is

\section{INTRODUCCIÓN}

El incremento en la población humana ha generado un aumento en las necesidades de alimentos de origen animal y cada vez se hace necesario la búsqueda de animales más eficientes y productivos desde diferentes perspectivas. El mejoramiento de algunas variables importantes en producción de leche se puede lograr con el uso de programas de selección adecuados, de acuerdo a las condiciones específicas donde se realicen, por lo que el conocimiento preciso de los parámetros genéticos y fenotípicos es crítico en el planeamiento y desarrollo de estrategias adecuadas de selección (1).

La estimación de parámetros genéticos y fenotípicos son necesarios para determinar el grado de variación de un caracter que es debido a la genética y al ambiente y también para predecir asociaciones genéticas entre dos o más variables. Estos parámetros son comúnmente requeridos para construir índices de selección y predecir respuestas correlacionadas y principalmente para realizar evaluaciones genéticas más eficientes (2).

La producción animal en ganado Holstein y Jersey presenta uno de los niveles más altos de tecnificación y son las razas especializadas más utilizadas para producción de leche en el trópico alto Colombiano. Sin embargo, la estimación de parámetros genéticos y fenotípicos y consecuentemente las evaluaciones genéticas han presentado serias dificultades, principalmente por la limitada cantidad de registros productivos periódicos y confiables para caracteres de importancia económica (3). Como consecuencia, las decisiones de selección acordes a las necesidades y condiciones propias del trópico han involucrado gran incertidumbre, especialmente en vacas y toros jóvenes (1).

Si bien la selección en ganado lechero en Colombia, ha sido dirigida a producción de leche, las variables asociadas a su calidad composicional, juegan un papel muy importante en los programas de selección genética, debido a que estas características 
considered to be a variable of milk quality, and is also associated with susceptibility that can be present in cows with subclinical mastitis (5), a disease that causes huge economic loss around the world (6).

Having genetic and phenotypic parameters available that are based on precise information that is more representative of conditions specific to the high Colombian tropics, which involves not just milk production but is also related to the compositional quality of milk and udder health, is greatly important for genetic improvement programs for Holstein and Jersey cattle. The objective of this study was to determine the genetic and phenotypic parameters for milk production, fat percentage, protein percentage, and somatic cell score (SCS) in Holstein and Jersey cattle in Antioquia, Colombia.

\section{MATERIALS AND METHODS}

Location. This investigation was based on information obtained from 156 Holstein farms and 36 Jersey farms from 18 municipalities in the department of Antioquia, at 2000 and 2600 m.a.s.l. and average temperatures between 13 and $17^{\circ} \mathrm{C}$. The conditions of handling, feeding and health were variable in different production systems, as well as topography and geographic location; however, all the animals were pastured and fed with balanced commercial feed.

Using information supplied by these farms in the milk control program at the Medellin headquarters of the Universidad Nacional de Colombia, productive data for fat percentage $(P G)$, protein percentage (PP), milk yield in lactation (PL) and somatic cell count (RCS) were used to estimate genetic and phenotypic parameters, after confirming their veracity. All the information from the herds was organized and saved in Control 1 software version 1.0 (7).

The information collected was reviewed in order to determine reliability, and records that were considered suspect were removed from the definitive analysis. Additionally, all totally atypical and physiologically abnormal data was removed, which was determined while processing and storing the information.

The RCS values were transformed into somatic cell score (SCS) by means of the mathematical equation: $\mathrm{SCS}=\left[\mathrm{LOG}_{2}(\mathrm{RCS} / 100000)+3\right]$ in order to improve normalcy in the data (5). The information was edited in order to obtain a record base that would be the most reliable and appropriate to the local situations. presentan un gran impacto económico en las empresas ganaderas (4). Adicionalmente, el recuento de células somáticas (RCS) que ha sido valorado como una variable de calidad de la leche, también se encuentra asociado con la susceptibilidad que puedan presentar las vacas a mastitis subclínica (5), enfermedad que genera grandes pérdidas económicas a nivel mundial (6).

Disponer de parámetros genéticos y fenotípicos usando información precisa y más representativa de las condiciones propias del trópico alto colombiano que involucre además de la producción de leche, caracteres asociadas a la calidad composicional de la leche y de salud de la ubre, serán de gran importancia para los programas de mejoramiento genético del ganado Holstein y Jersey. El objetivo del presente estudio fue determinar los parámetros genéticos y fenotípicos para producción de leche, porcentaje de grasa, porcentaje de proteína y puntaje de células somáticas (SCS) en ganado Holstein y Jersey de Antioquia, Colombia.

\section{MATERIALES Y MÉTODOS}

Localización. La presente investigación se desarrolló con base en la información obtenida de 156 hatos Holstein y 36 hatos Jersey, de 18 municipios del departamento de Antioquia, con alturas entre 2000 a 2600 m.s.n.m. y con temperaturas promedio entre 13 y $17^{\circ} \mathrm{C}$. Las condiciones de manejo, alimentación y sanidad fueron cambiantes en los diferentes sistemas de producción, así como su topografía y ubicación geográfica; sin embargo, todos los animales se encontraban en pastoreo y suplementados con alimento balanceado comercial.

Teniendo en cuenta la información suministrada por estos hatos en el programa de control lechero de la Universidad Nacional de Colombia, Sede Medellín, se obtuvieron datos productivos para porcentaje de grasa $(\mathrm{PG})$, porcentaje de proteína (PP), producción de leche por lactancia (PL) y recuento de células somáticas (RCS), los cuales se utilizaron en la estimación de los parámetros genéticos y fenotípicos, previa confirmación de la veracidad de los mismos. Toda la información de los hatos fue organizada y almacenada en el software Control 1, versión 1.0 (7).

La información recolectada fue revisada con el fin de determinar su confiabilidad, de tal manera que los registros sobre los que se encontró sospecha de su validez fueron retirados de los análisis definitivos. Adicionalmente, se retiraron todos los datos totalmente atípicos y fisiológicamente anormales, los cuales se pudieron generar en el procesamiento y almacenamiento de la información. 
Sample size. Once the information was edited, 18134 animal records remained; 7723 animals with PL records, 5709 with PG records, 5866 with PP and 5769 with RCS. In the case of Jersey cattle, 1.377 animal records were used: 820 with PL records, 455 with PG, 475 with PP and 471 with RCS. The number of animals in the kinship matrix for the Holstein breed was 9099 and for the Jersey breed was 801 .

Statistical analysis. A descriptive analysis was performed in which the measurements, standard deviation, and variation coefficients were estimated for each variable in the two breeds. Also, normality suppositions were validated, as well as independence and homoscedasticity, using different procedures of the SAS/STAT program (8).

Components of variance, heritability and repeatability. Preliminary analysis was used to test models that included different fixed effects and covariables in order to determine the statistical models that best fit the estimates of genetic parameters of the different productive traits evaluated.

The components of variance and genetic parameters were estimated based on an independent univariate animal model for each trait. This was done by means of the restricted maximum likelihood method (REML) using the SAS statistical package (8) and MTDFREML (9) that determine solutions based on the equations of mixed models (MME) described by Henderson (10).

The univariate animal model used included the following fixed effects: the herd, number of births and contemporary group (with municipality, year of birth and season of birth). As a covariable, it included the duration of lactation (only for PL) and milk yield in the case of PP and PG variables. Finally, as random effects, the permanent environment and direct additive genetic effect of the animal was included.

The model used was the following:

$Y=X \beta+Z a+W n+e$

Where:

$\mathrm{Y}=$ vector of observations for $\mathrm{PL}, \mathrm{PP}, \mathrm{PG}$ and SCS; $\beta=$ unknown vector of fixed effects (the herd, number of births and contemporary group and as covariables the duration of lactation for PL and milk yield for PG and PP); $\alpha=$ unknown vector of random animal effects; $\Pi_{i}=$ unknown vector of permanent random environmental effects; $e=$ unknown vector of random residual effects; $X=$ Incidence matrix of fixed effects,
Los valores de RCS fueron trasformados a puntaje de células somáticas (SCS) mediante la ecuación matemática: SCS = [LOG $($ RCS/100000) + 3], para mejorar la normalidad de los datos (5). La edición de la información se hizo básicamente buscando obtener una base de registros lo más confiable y acordes a las situaciones locales.

Tamaño muestral. Una vez realizada la edición de la información, se contó con 18134 registros de animales, de los cuales se utilizó la información definitiva de 7723 animales que poseían registros de PL, 5709 que tenían registros para PG, 5866 para PP y 5769 para RCS. Para el caso de Jersey se utilizaron 1.377 registros de animales, de los cuales se contó con 820 registros para PL, 455 para PG, 475 para PP y 471 para RCS. El número de animales en la matriz de parentesco para la raza Holstein fue de 9099 y para la raza Jersey de 801 animales.

Análisis estadístico. Se llevó a cabo un análisis descriptivo en el cual se estimaron las medias, las desviaciones estándar y los coeficientes de variación para cada variable en las dos razas. Además, se validaron los supuestos de normalidad, de independencia y de homocedasticidad usando diferentes procedimientos del programa SAS/STAT (8).

Componentes de varianza, heredabilidad y repetibilidad. Mediante un análisis preliminar se probaron modelos que incluyeron diferentes efectos fijos y covariables, con el fin de determinar los modelos estadísticos que mejor se ajustaban para la estimación de los parámetros genéticos de las diferentes características productivas evaluadas.

Los componentes de varianza y los parámetros genéticos se estimaron basados en un modelo animal univariado independiente para cada una de las características. Se realizó mediante el método de máxima verosimilitud restricta (REML), utilizando el paquete estadístico SAS (8) y MTDFREML (9) que determinan las soluciones basados en las ecuaciones de modelos mixtos (MME) descritas por Henderson (10).

El modelo animal univariado utilizado incluyó como efectos fijos: el hato, número de parto y grupo contemporáneo (conformado por municipio, año de parto y época de parto). Como covariable se incluyó la duración de la lactancia (sólo para PL) y la producción de leche en el caso de las variables PP y PG. Finalmente, como efectos aleatorios se incluyó el ambiente permanente y el efecto genético aditivo directo del animal.

El modelo utilizado fue el siguiente:

$\mathrm{Y}=\mathrm{X} \beta+\mathrm{Za}+\mathrm{W} n+\mathrm{e}$ 
$Z=$ Incidence matrix of random animal effects and $\mathrm{W}=$ incidence matrix of random permanent environmental effects.

The above model assumes that the random effects of the animal, permanent environment and residual effects are independently distributed with zero mean and variances $\sigma_{\alpha}^{2}, \sigma_{\pi \mathrm{y}}^{2} \sigma_{e}^{2}$, respectively.

Using the above model, a narrow sense of heritability was determined, which was estimated as: $h^{2}=\sigma_{\alpha}^{2} /\left(\sigma_{\alpha}^{2}+\sigma_{\pi}^{2}+\sigma_{e}^{2}\right)$ and repeatability was estimated using the equation: $r=\left(\sigma_{\alpha}^{2}+\sigma_{\pi}^{2}\right) /\left(\sigma_{\alpha}^{2}+\sigma_{\pi}^{2}+\sigma_{e}^{2}\right)(11)$. The heritability and repeatability parameters with their respective standard errors were obtained using MTDFREML software (9).

It is important to keep in mind that the univariate model makes it possible to break down the variability of the character without taking into account the effect of other secondary numeric variables. For this reason, a unicaracteristic model was made to compare and define just one estimate, since the bicharacteristic model generates different estimates according to the paired set of variables that are evaluated in the model. It is also important to mention that the estimates for the bicharacteristic model depend on evaluating individuals that present information for both traits, so that the size can change with each set of variables evaluated in the model.

\section{Components of (co)variance and genetic} and phenotypic correlations. The (co) variance components were estimated using a derivative free restricted maximum likelihood method (10) using MTDFREML software (9) and a bicharacteristic model that includes fixed effects for both variables: herd, birth number and contemporary group (with municipality, year of birth and season of birth). Random effects that were included were the permanent environmental effect and the additive effect of the animal. The matrix model used was:

$\left[\begin{array}{l}Y_{1} \\ Y_{2}\end{array}\right]=\left[\begin{array}{cc}X_{1} & 0 \\ 0 & X_{2}\end{array}\right]\left[\begin{array}{c}\beta_{1} \\ \beta_{2}\end{array}\right]+\left[\begin{array}{cc}Z_{1} & 0 \\ 0 & Z_{2}\end{array}\right]\left[\begin{array}{c}\alpha_{1} \\ \alpha_{2}\end{array}\right]+\left[\begin{array}{cc}W_{1} & 0 \\ 0 & W_{2}\end{array}\right]\left[\begin{array}{c}\pi_{1} \\ \pi_{2}\end{array}\right]+\left[\begin{array}{l}\varepsilon_{1} \\ \varepsilon_{2}\end{array}\right]$

Where: $Y_{i}=$ vector of $\mathrm{n}$ observations for each $\mathrm{i}$ trait (PL, PP, PG y SCS); $\beta_{\mathrm{i}}=$ solution vector for fixed effects (herd, birth number and contemporary group, and as covariables lactation duration for $\mathrm{PL}$ and milk yield for PG and PP); $a_{i}=$ solution vector for random animal effects; $\Pi_{\mathrm{i}}=$ solution vector for random permanent environmental effects; $\mathrm{e}=$ vector for residual wastes; $X_{i}=$ Matrix of incidence of fixed effects, $Z_{i}=$ matrix of incidence for random animal effects and $W_{i}=$ Matrix of incidence of random permanent environmental effects.
Donde:

$\mathrm{Y}=$ vector de observaciones para $\mathrm{PL}, \mathrm{PP}, \mathrm{PG}$ y SCS; $\beta=$ vector desconocido de efectos fijos (hato, número de parto y grupo contemporáneo y las covariables duración de la lactancia para $\mathrm{PL}$ y producción de leche para PG y PP); $\boldsymbol{\alpha}=$ vector desconocido de efectos aleatorios del animal; $\Pi_{i}=$ vector desconocido de efectos aleatorios del ambiente permanente; $\mathrm{e}=$ vector desconocido de efectos aleatorios residuales; $X=$ Matriz de incidencia de los efectos fijos, $Z=$ matriz de incidencia los efectos aleatorios del animal y $\mathrm{W}=$ matrices de incidencia de los efectos aleatorios del ambiente permanente.

El modelo anterior asume que los efectos aleatorios del animal, del ambiente permanente y el residual, se distribuyen independientemente con media cero y varianzas $\sigma_{\alpha}^{2}, \sigma_{\pi}^{2}$ y $\sigma_{e}^{2}$, respectivamente.

Mediante el modelo anterior se determinó la heredabilidad en el sentido estrecho, la cual se estimó como: $h^{2}=\sigma_{\alpha}^{2} /\left(\sigma_{\alpha}^{2}+\sigma_{\pi}^{2}+\sigma_{e}^{2}\right)$ y la repetibilidad que se estimó mediante la ecuación: $r=\left(\sigma_{\alpha}^{2}+\sigma_{\pi}^{2}\right) /\left(\sigma_{\alpha}^{2}+\sigma_{\pi}^{2}+\sigma_{e}^{2}\right)(11)$. Los parámetros de heredabilidad y repetibilidad con sus respectivos errores estándar fueron obtenidos mediante el software MTDFREML (9).

Es importante tener en cuenta que el modelo univariado permite descomponer la variabilidad del caracter sin tener en cuenta el efecto de las otras variables numéricas secundarias. Por este motivo, se realizó un modelo unicaracterístico para comparar y definir una sola estimación, ya que el modelo bicaracterístico genera diferentes estimaciones de acuerdo al conjunto de variables pareadas que se evalúan en el modelo. Por otra parte es importante mencionar que las estimaciones por el modelo bicaracterístico tienen dependencia a evaluar los individuos que presentan información para ambas características, por lo que el tamaño empleado puede cambiar con cada par de variables diferentes evaluadas en el modelo.

Componentes de (co)varianza, correlaciones genéticas y fenotípicas. Los componentes (co)varianza se estimaron mediante máxima verosimilitud restricta libre de derivada (10), mediante el software MTDFREML (9) usando un modelo bicaracterístico incluyendo para ambas variables los efectos fijos: hato, número de parto y grupo contemporáneo (compuesto por municipio, año de parto y época de parto). Como efectos aleatorios se incluyeron el efecto del ambiente permanente y el efecto aditivo del animal. El modelo matricial utilizado fue:

$\left[\begin{array}{l}Y_{1} \\ Y_{2}\end{array}\right]=\left[\begin{array}{cc}X_{1} & 0 \\ 0 & X_{2}\end{array}\right]\left[\begin{array}{l}\beta_{1} \\ \beta_{2}\end{array}\right]+\left[\begin{array}{cc}Z_{1} & 0 \\ 0 & Z_{2}\end{array}\right]\left[\begin{array}{l}\alpha_{1} \\ \alpha_{2}\end{array}\right]+\left[\begin{array}{cc}W_{1} & 0 \\ 0 & W_{2}\end{array}\right]\left[\begin{array}{l}\pi_{1} \\ \pi_{2}\end{array}\right]+\left[\begin{array}{l}\varepsilon_{1} \\ \varepsilon_{2}\end{array}\right]$ 
The above model assumes that the random effects (random animal effects, random permanent environmental effects and residual random effect) are independently distributed with zero mean and variances, $\sigma_{\alpha}^{2}, \sigma_{\pi}^{2}$ and $\sigma_{e}^{2}$ respectively.

The genetic $\left(r_{p}\right)$ and phenotypic $\left(r_{p}\right)$ correlations among the different traits evaluated were determined using the following equations:

$r_{g}=\frac{\sigma_{a i j}}{\sqrt{\sigma_{a i}^{2} \sigma_{a j}^{2}}}, r_{p}=\frac{\sigma_{p i j}}{\sqrt{\sigma_{p i}^{2} \sigma_{p j}^{2}}}$

Where: $\sigma_{a i j}=$ genetic covariance for traits i and

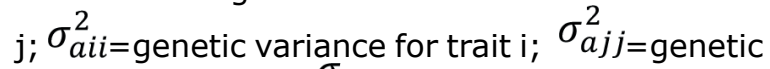
variance for trait j; $\sigma_{p i j=\text { phenotypic covariance }}$ for traits $\mathrm{i}$ and $\mathrm{j} ; \sigma_{p i i}^{2}=$ phenotypic variance for traits $i$ and $\sigma_{p j j}^{2}=$ phenotypic variance for trait $j$.

\section{RESULTS}

Descriptive analysis. With the descriptive evaluation it was possible to determine that the mean for PL was $5524 \pm 2156$ and $4234 \pm 1869$ liters/lactation for Holstein and Jersey breeds, respectively, with a coefficient of variation of $39.0 \%$ for Holstein and $44.2 \%$ for Jersey, which was the trait that most varied between the two breeds (Table 1). On the other hand, the trait that varied the least was $\mathrm{PP}$, with variation coefficients of $9.2 \%$ and $8.8 \%$ for Holstein and Jersey, respectively. All the traits presented variation coefficients according to what was expected for the production systems in which the investigation was done. In general, the estimates obtained make it possible to observe a greater PL in the Holstein breed. However, milk produced in the Jersey breed presents greater percentages of fat and protein.

Table 1. Descriptive analysis for milk yield per lactation $(P L)$, fat percentage (PG), protein percentage (PP) and somatic cell score (SCS) in Holstein and Jersey cows in Antioquia (Colombia).

\begin{tabular}{clcccc}
\hline Breed & \multicolumn{1}{c}{ Trait } & N & Mean & DE & CV \\
\hline \multirow{6}{*}{ Holstein } & PL (liters/ & 7723 & 5524 & 2156 & 39.0 \\
& lactation) & & & & \\
& PP (\%) & 5866 & 3.06 & 0.28 & 9.2 \\
& PG (\%) & 5709 & 3.88 & 0.46 & 11.8 \\
& SCS & 5769 & 4.67 & 1.37 & 29.5 \\
\hline \multirow{5}{*}{ Jersey } & PL (liters/ & 820 & 4234 & 1869 & 44.2 \\
& lactation) & & & & \\
& PP (\%) & 475 & 3.44 & 0.30 & 8.8 \\
& PG (\%) & 455 & 4.66 & 0.60 & 12.9 \\
& SCS & 471 & 4.22 & 1.36 & 32.2 \\
\hline
\end{tabular}

$\mathrm{DE}=$ stand
records.
Dónde: $Y_{i}=$ vector de $n$ observaciones para cada i característica (PL, PP, PG y SCS); $\beta_{\mathrm{i}}=$ vector de solución para los efectos fijos (hato, número de parto y grupo contemporáneo y las covariables duración de la lactancia para PL y producción de leche para PG y PP); $a_{i}=$ vector de solución para los efectos aleatorios del animal; $\Pi_{i}=$ vector de solución para los efectos aleatorios del ambiente permanente; $\mathrm{e}=$ vector de efectos residuales; $X_{i}=$ Matriz de incidencia de los efectos fijos, $Z_{i}=$ matriz de incidencia los efectos aleatorios del animal y $W_{i}=$ matrices de incidencia de los efectos aleatorios del ambiente permanente.

El modelo anterior asume que los efectos aleatorios (efecto aleatorio del animal, efecto aleatorio del ambiente permanente y efecto aleatorio residual) se distribuyen independientemente con media cero y varianzas $\sigma_{\alpha}^{2}, \sigma_{\pi}^{2}$ y $\sigma_{e}^{2}$, respectivamente.

Las correlaciones genéticas $\left(r_{q}\right)$ y fenotípicas $\left(r_{p}\right)$ entre las diferentes características evaluadas, fueron determinadas mediante las siguientes ecuaciones:

$r_{g}=\frac{\sigma_{a i j}}{\sqrt{\sigma_{a i}^{2} \sigma_{a j}^{2}}}, r_{p}=\frac{\sigma_{p i j}}{\sqrt{\sigma_{p i}^{2} \sigma_{p j}^{2}}}$

Dónde: $\sigma_{a i j}=$ covarianza genética para las características i y j; $\sigma_{a i i}^{2}=$ varianza genética para la característica i; $\sigma_{a j j}^{2}=$ varianza genética para la característica $j ; \sigma_{p i j}=$ covarianza fenotípica para las características i y j; $\sigma_{p i i}^{2}=$ varianza fenotípica para la característica i y $\sigma_{p j j}^{2}=$ varianza fenotípica para la característica $j$.

\section{RESULTADOS}

Análisis descriptivo. La evaluación descriptiva permitió determinar que la media para PL fue $5524 \pm 2156$ y $4234 \pm 1869$ litros/lactancia para las razas Holstein y Jersey, respectivamente, con un coeficiente de variación de $39.0 \%$ para Holstein y $44.2 \%$ para Jersey, siendo la característica que más varió en las dos razas (Tabla 1 ). Por otra parte, la característica que menos varió fue PP con coeficientes de variación de $9.2 \%$ y $8.8 \%$ para Holstein y Jersey, respectivamente. Todas las características presentaron coeficientes de variación acordes con lo esperado para los sistemas de producción en los que se realizó la investigación. En general las estimaciones obtenidas permiten evidenciar una mayor PL en la raza Holstein. Sin embargo, la leche producida en la raza Jersey presenta mayores porcentajes de grasa y proteína. 
Heritability and repeatability. The trait that presented the greatest heritability was PG, with values of 0.32 and 0.46 for Holsteins and Jerseys, respectively; the lesser heritability was SCS with values of $0.01 \mathrm{I}$ both breeds. The results show that heritability for SCS were lower $\left(h^{2}<5 \%\right)$, however the repeatability is much higher with values of 0.26 and 0.41 for Holstein and Jersey, respectively, which shows that the permanent environment had a very important effect on this trait.

The heritability for PG and PP were average $(0.32$ and 0.30$)$ for Holstein, however the Jersey breed presented higher heritability ( 0.46 and 0.47 , respectively) for the traits mentioned (Table 2). Regarding milk yield per lactation, the heritability was 0.16 and 0.15 for Holsteins and Jerseys. However, repeatability was much higher, ( 0.30 and 0.32 , respectively), which showed an important effect in the permanent environment on this trait in the two breeds.

Table 2. Heritability and repeatability for milk yield per lactation $(P L)$, fat percentage (PG), protein percentage (PP) somatic cell score (SCS) in Holstein and Jersey cows in Antioquia (Colombia).

\begin{tabular}{cccc}
\hline Breed & Trait & $\mathbf{h}^{2}(\mathrm{EE})$ & $\mathbf{R}(\mathrm{EE})$ \\
\hline \multirow{6}{*}{ Holstein } & PL & $0.16(0.082)$ & $0.30(0.082)$ \\
& PP & $0.30(0.079)$ & $0.30(0.079)$ \\
& PG & $0.32(0.076)$ & $0.42(0.077)$ \\
\multirow{3}{*}{ Jersey } & SCS & $0.01(0.054)$ & $0.26(0.058)$ \\
\hline & PL & $0.15(0.306)$ & $0.32(0.309)$ \\
& PP & $0.37(0.319)$ & $0.48(0.319)$ \\
& PG & $0.46(0.313)$ & $0.57(0.313)$ \\
& SCS & $0.01(0.233)$ & $0.41(0.242)$ \\
\hline
\end{tabular}

$\mathrm{h}^{2}=$ heritability; $\mathrm{R}=$ repeatability; $\mathrm{EE}=$ standard error.

Genetic and phenotypic correlations. The highest genetic correlation was found between PG and $\mathrm{PP}$, with values of 0.82 and 0.98 for Holstein (Table 3) and Jersey (Table 4), respectively, which indicates a very strong positive genetic association between the two milk components. On the other hand, the phenotypic correlation between the two traits was lower than the genetic due to environmental factors that affect them.

The lowest genetic correlation obtained was for PG and SCS ( -0.01 for the two breeds). However, the phenotypic correlation was a little higher ( 0.12 and 0.15 for Holstein and Jersey).

The genetic correlation between PL and PP and between PL and PG in Holstein cattle was negative, with values at -0.40 and -0.28 , respectively (Table 3 ). In the two breeds, the
Heredabilidad y repetibilidad. La característica que presentó mayor heredabilidad fue PG con valores de 0.32 y 0.46 para las razas Holstein y Jersey respectivamente; la de menor heredabilidad fue SCS con valores de 0.01 en ambas razas. Los resultados muestran que las heredabilidades para SCS fueron muy bajas $\left(h^{2}<5 \%\right)$, sin embargo la repetibilidad es mucho más alta con valores de 0.26 y 0.41 para Holstein y Jersey, respectivamente, lo cual evidencia un efecto muy importante del ambiente permanente para esta característica.

Las heredabilidades para PG y PP fueron medias (0.32 y 0.30 ) para la raza Holstein, sin embargo la raza Jersey presentó heredabilidades más altas (0.46 y 0.47 , respectivamente) para las características mencionadas (Tabla 2). Con respecto a la producción de leche por lactancia, la heredabilidad fue de 0.16 y 0.15 para la raza Holstein y Jersey. Sin embargo, la repetibilidad fue mucho mayor ( 0.30 y 0.32 , respectivamente), lo cual evidencia un efecto importante del ambiente permanente sobre esta característica en las dos razas.

Correlaciones genéticas y fenotípicas. La correlación genética más alta se encontró entre PG y PP, con valores de 0.82 y 0.98 para Holstein (Tabla 3) y Jersey (Tabla 4), respectivamente, lo cual indica una asociación genética positiva muy fuerte entre los dos componentes de la leche. Por otra parte, la correlación fenotípica entre las dos características fue más baja que la genética, debido a los factores ambientales que las afectan.

La correlación genética más baja obtenida fue para PG y SCS (-0.01 para las dos razas). Sin embargo, la correlación fenotípica resultó ser un poco más alta (0.12 y 0.15 para Holstein y Jersey).

La correlación genética entre PL y PP y entre PL y PG en ganado Holstein fueron negativas, con valores de -0.40 y -0.28 , respectivamente (Tabla 3 ). En el caso del ganado Jersey las correlaciones fueron de -0.13 y -0.28 respectivamente. En las dos razas

Table 3. Genetic correlations (above the diagonal) and phenotypic correlations (below the diagonal) between productive traits in Holstein cows in Antioquia (Colombia).

\begin{tabular}{lcccc}
\hline \multicolumn{1}{c}{ Trait } & $\begin{array}{c}\text { PL } \\
\text { (EE) }\end{array}$ & $\begin{array}{c}\text { PP } \\
\text { (EE) }\end{array}$ & $\begin{array}{c}\text { PG } \\
\text { (EE) }\end{array}$ & $\begin{array}{c}\text { SCS } \\
\text { (EE) }\end{array}$ \\
\hline Milk yield (PL) & 1 & $\begin{array}{c}-0.40 \\
(0.137)\end{array}$ & $\begin{array}{c}-0.28 \\
(0.190)\end{array}$ & $\begin{array}{c}0.08 \\
(1.200)\end{array}$ \\
$\begin{array}{lccc}\text { Protein percentage } \\
\text { (PP) }\end{array}$ & -0.22 & & 0.82 & 0.28 \\
Fat percentage & $(0.013)$ & 1 & $(0.126)$ & $(0.940)$ \\
(PG) & -0.11 & 0.48 & & -0.01 \\
$\begin{array}{l}\text { Somatic cell score } \\
\text { (SCS) }\end{array}$ & $-0.014)$ & $(0.010)$ & 1 & $(1.147)$ \\
\hline EE=standard error & $(0.014)$ & 0.17 & 0.12 & 1 \\
& & & & \\
\end{tabular}

$\mathrm{EE}=$ standard error 
phenotypic correlations between PL and PG were negative, however the phenotypic correlation between PL and PP were positive but very low in Jersey cattle, although it should be kept in mind that they presented a high standard error (Table 4). In general, all the phenotypic correlations were lower than the genetic ones.

Table 4. Matrix of genetic correlations (above the diagonal) and phenotypic correlations (below the diagonal) between productive traits in Jersey cows in Antioquia (Colombia).

\begin{tabular}{lcccc}
\hline \multicolumn{1}{c}{ Trait } & $\begin{array}{c}\text { PL } \\
\text { (EE) }\end{array}$ & $\begin{array}{c}\text { PP } \\
\text { (EE) }\end{array}$ & $\begin{array}{c}\text { PG } \\
\text { (EE) }\end{array}$ & $\begin{array}{c}\text { SCS } \\
\text { (EE) }\end{array}$ \\
\hline Milk yield (PL) & 1 & -0.13 & -0.28 & 0.10 \\
& & $(0.884)$ & $(0.982)$ & $(1.947)$ \\
Protein & 0.07 & & 0.98 & 0.19 \\
production (PP) & $(0.049)$ & 1 & $(0.852)$ & $(1.904)$ \\
$\begin{array}{l}\text { Fat percentage } \\
\text { (PG) }\end{array}$ & -0.45 & 0.25 & & -0.01 \\
Somatic cell & $(0.040)$ & $(0.044)$ & 1 & $(1.734)$ \\
score (SCS) & 0.09 & 0.11 & 0.15 & \\
\hline
\end{tabular}

$\mathrm{EE}=$ standard error

\section{DISCUSSION}

The standard error of heritability in the different variables evaluated in Jersey cattle was very high, which suggests implications concerning the reliability of the estimates. In Holstein cattle, a lower standard error was obtained in the estimates mainly due to a greater sampling size and reliability of the records.

The milk quality traits (PP and PG) presented mean heritability values (greater than $20 \%$ ) and a low permanent environmental effect in the two breeds. However, the Jersey breed presented greater heritability values than Holstein, both for PG and for PP, although with a greater standard error. Additionally, heritability for PG was greater than for $\mathrm{PP}$, which is in agreement with some authors (12), although not with others (13). However, both traits were highly correlated.

Milk yield per lactation (PL) presented heritability lower than $20 \%$ in the two evaluated breeds, showing an important influence from the permanent environment on this trait, which made possible a greater repeatability. Additionally, it is important to make clear that PL was the trait that had the greatest number of repeated records per animal, with an average of 1.9 , even with cows that had 7 lactations, and more than $68 \%$ of the animals had production records for more than one lactation.

For SCS, the low heritability for this trait was confirmed $(0.01)$ both in the Holstein and Jersey breeds, suggesting the high influence las correlaciones fenotípicas entre PL y PG fueron negativas, sin embargo la correlación fenotípica entre PL y PP fueron positivas pero muy bajas en el ganado Jersey, aunque se debe tener en cuenta que presentaron un alto error estándar (Tabla 4). En general todas las correlaciones fenotípicas fueron más bajas que las genéticas.

\section{DISCUSIón}

El error estándar de la heredabilidad en las diferentes variables evaluadas en el ganado Jersey fue muy alto, lo que sugiere implicaciones acerca de la confiabilidad de las estimaciones. En ganado Holstein se obtuvo menor error estándar en las estimaciones debido principalmente al mayor tamaño de muestra y a la confiabilidad de los registros.

Las características de calidad de la leche (PP y PG) presentaron valores medios de heredabilidad (mayores al $20 \%$ ) y un bajo efecto del ambiente permanente en las dos razas. Sin embargo, la raza Jersey presentó mayores valores de heredabilidad que Holstein, tanto para el PG como para PP, aunque con un mayo error estándar. Adicionalmente, la heredabilidad para PG fue mayor que para PP, lo cual se encuentra acorde con algunos autores (12), aunque discordó con otros (13). Sin embargo, ambas características se encontraron altamente correlacionadas.

La producción de leche por lactancia (PL) presentó heredabilidades más baja que el $20 \%$ en las dos razas evaluadas, evidenciando una influencia importante del ambiente permanente para esta característica, lo que permitió obtener una mayor repetibilidad. Adicionalmente, es importante aclarar que PL fue la característica que presentó el mayor número de registros repetidos por animal, con un promedio de 1.9, incluso con vacas que presentaban hasta 7 lactancias y donde más del $68 \%$ de los animales presentaban registros de producción para más de una lactancia.

Para SCS, se confirmó la baja heredabilidad que presenta esta característica (0.01) tanto en la raza Holstein como Jersey, sugiriendo una alta influencia de los factores ambientales sobre esta variable (14). Sin embargo, la repetibilidad fue mayor en las dos razas, dejando ver el efecto importante del ambiente permanente. Estos resultados concuerdan con lo encontrado en otros estudios $(14,15)$.

Los valores medios obtenidos para las características de calidad de la leche (PP y PG), se encuentran acordes con los valores encontrados en la literatura que permite catalogarlas como de heredabilidad media a alta $(16,13)$. Sin embargo, son menores que algunas reportados en Colombia (2) y mayores 
of environmental factors on this variable 814). However, repeatability was greater in the two breeds, showing the important effect that the permanent environment has. These results agree with those found in other studies $(14,15)$.

The mean values obtained for milk quality traits (PP and PG) are in agreement with the values found in literature that catalogues them as medium to high heritability $(16,13)$. However, they are less than some reported in Colombia (2) and greater than other reports in other parts of the world $(12,17)$. The estimated repeatability for these characteristics is also found in concordance with different reports presented for dairy cattle, showing that the permanent environment has a lesser importance on solids present in the milk (18).

Milk yield per lactation showed heritability of 0.16 and 0.15 for Holstein and Jersey respectively, but with a greater standard error than for Jersey cattle, values which were lower than cases found in literature $(12,19,20)$ that show values above 0.2 and that indicate that milk yield is a trait with medium heritability. However, some authors have found similar values to those obtained in this study, confirming a lower heritability in PL when compared with PG and PP and cataloguing the trait as medium or low heritability (21). On the other hand, the repeatability for this trait is double in magnitude when compared with heritability, which shows the huge effect that the permanent environment has. Similar results have been reported in other studies (22).

The somatic cell score (SCS) presented low heritability $(0.01)$ and the highest standard error in both breeds, which is according to what is found in literature $(15,21)$. These results suggest that the traits association with udder health are not highly inheritable, which constitutes a problem for genetic improvement programs. However, the majority of reports suggest a slightly higher heritability than that found in this study $(14,16)$. Most research has encountered difficulties in improving this trait and in many cases suggests the need to reinforce genetic improvement programs with other methods in order to obtain a more accelerated genetic progress, such as assisted selection using molecular markers and genomic selection.

On the other hand, higher values for repeatability were found, suggesting the important effect the permanent environment has, which agrees with some reports $(14,15)$. However, genetic progress in these traits is greatly affected by the environment, so good herd management can greatly improve this situation. que otros reportes en otras partes del mundo $(12,17)$. Las repetibilidades estimadas para éstas características también se encuentran en concordancia con diferentes reportes presentados para ganado lechero, evidenciando una menor importancia del ambiente permanente sobre los sólidos presentes en la leche (18).

La producción de leche por lactancia presentó heredabilidades de 0.16 y 0.15 para Holstein y Jersey respectivamente, pero con mayor error estándar para el ganado Jersey, valores que se encuentran en algunos casos por debajo de lo encontrado en la literatura $(12,19,20)$, que plantean valores mayores de 0.2 y que permiten catalogar la producción de leche como una característica de mediana heredabilidad. Sin embargo, algunos autores han encontrado valores semejantes a los obtenidos en el presente trabajo corroborando una menor heredabilidad en $\mathrm{PL}$ con respecto al PG y PP y catalogando la característica como de heredabilidad media a baja (21). Por otra parte, la repetibilidad para esta característica es del doble en magnitud que la heredabilidad, lo que evidencia un gran efecto del ambiente permanente. Resultados similares han sido reportados en otros trabajos (22).

El puntaje de células somáticas (SCS) presentó una heredabilidad baja (0.01) y el mayor error estándar en las dos razas, lo cual está acorde con lo encontrado en la literatura $(15,21)$. Estos resultados sugieren que las características asociadas a la salud de la ubre son poco heredables, lo que constituye un problema para los programas de mejoramiento genético. Sin embargo, la mayoría de reportes sugieren heredabilidades un poco más altas a las encontrados en el presente trabajo $(14,16)$. La mayor parte de las investigaciones encuentran dificultades para mejorar esta característica y se plantea en muchos casos la necesidad de reforzar los programas de mejoramiento genético con otras metodologías que permitan obtener un progreso genético más acelerado como la selección asistida por marcadores moleculares y la selección genómica.

Por otra parte, la repetibilidad presentó valores más altos, sugiriendo un efecto importante del ambiente permanente, lo que concuerda con algunos reportes de la literatura $(14,15)$. Sin embargo, el progreso genético para estas características tiene gran influencia ambiental, por lo que el buen manejo al interior de los hatos puede contribuir en gran medida a su mejora.

La correlación genética, entendida como la probabilidad de que dos características diferentes sean influenciadas por los mismos genes, se evidencia como la asociación de los valores 
The genetic correlation, understood as the probability that two different characteristics are influenced by the same genes, is seen as the association of genetic values of one trait on those of another (11). Keeping this in mind, this study determined the existing correlations between productive traits (PL, PP, PG and SCS) in Holstein and Jersey breeds, finding a high correlation between traits associated with milk quality (PP and $P G)$ but a medium to low correlation in the rest.

Genetic correlations between PG and PP were 0.82 and 0.98 for Holstein and Jersey, respectively, which agrees with the results obtained by other authors that have reported high genetic correlations between these two traits (greater than $70 \%$ ) in different milk breeds $(17,22)$, although in Colombia lower correlations have been estimated (23). The magnitude and direction found in this genetic correlation means that when one of this traits is selected, the other is also selected, resulting in a joint genetic progress. However, it is important to remember that the size of the sample used and the standard error obtained in the Jersey breed is very high, and should therefore be used with caution due to reliability problems.

The genetic correlation between PP and PL was negative in both breeds; however, the importance of the association was much greater in Holstein than Jersey cattle. The above results agree with what has been found in literature, where negative associations for these two traits are well known $(17,23)$. However, the Jersey breed has lower values than those reported in the majority of work done on dairy cattle, although it should be kept in mind that the standard error in all estimates is very high, which implies that the results obtained in this breed should be taken with precaution due to reliability problems attributed mainly to the small sample size and the reliability of the data.

Genetic association between PL and PG was also negative for both breeds, agreeing with that found in literature (24) and showing difficulty to improve the quality of milk and quantity at the same time, although estimations for the Jersey breed show the same problem associated with standard error that was mentioned previously.

Genetic correlation between PP and SCS was 0.28 and 0.19 for Holstein and Jersey, respectively, which, although still low, agree with what was reported by VanRaden et al (19). However, it is important to keep in mind that the standard error for the correlation between the two breeds is high, and that in general the estimates for SCS were more reliable when compared with other traits. genéticos de una característica sobre los de la otra (11). Teniendo en cuenta lo anterior, en el presente trabajo se determinaron las correlaciones existentes entre características productivas (PL, PP, PG y SCS) en las razas Holstein y Jersey, encontrándose altas correlaciones entre las características asociadas a calidad de la leche (PP y PG), pero una correlación media a baja entre las demás.

La correlaciones genéticas entre PG y PP fueron de 0.82 y 0.98 para Holstein y Jersey, respectivamente, lo cual concuerda con los resultados obtenidos por diferentes autores que han reportado altas correlaciones genéticas entre estas dos características (mayores al $70 \%$ ) en diferentes razas lecheras $(17,22)$, aunque en Colombia se han estimado correlaciones menores (23). La magnitud y dirección encontrada en esta correlación genética permite que cuando se seleccione para una de estas características indirectamente la otra también se seleccione y se obtiene un progreso genético conjunto. Sin embargo, es importante tener en cuenta el tamaño de la muestra utilizado y el error estándar obtenido en la raza Jersey es muy alto y por lo tanto debe ser tomado con cautela, debido a los problemas de confiabilidad que presenta.

La correlación genética entre PP y PL fue negativa en ambas razas, sin embargo, la magnitud de la asociación fue mucho mayor en la raza Holstein que en la Jersey. Los resultados anteriores concuerdan con lo encontrado en la literatura donde las asociaciones negativas para estas dos características son muy conocidas $(17,23)$. Sin embargo, para la raza Jersey los valores son más bajos que los que se encuentran reportados en la mayoría de trabajos realizados con ganado de leche, aunque se debe tener en cuenta que el error estándar de todas las estimaciones es muy grande, lo que implica que los resultados obtenido en esta raza deben ser tomados con precaución debido a problemas de confiabilidad atribuidos principalmente al pequeño tamaño muestral y a la confiabilidad de los datos.

La asociación genética entre PL y PG también fue negativa para ambas razas, concordando con lo encontrado en la literatura (24) y evidenciando una dificultad para mejorar la calidad de la leche y la cantidad al mismo tiempo, aunque para la raza Jersey las estimaciones presentan el mismo problema asociado al error estándar que se mencionó anteriormente.

La correlación genética entre PP y SCS fue de 0.28 y 0.19 para Holstein y Jersey, respectivamente, que siendo aún baja, concuerda con lo reportado por VanRaden et al (19). Sin embargo, es importante tener en cuenta que el error estándar para la correlación en las dos razas es alto y que en general las estimaciones para SCS tuvieron la menor confiabilidad comparado con las otras características. 
Other genetic correlations were lower (less than 0.1 ) and with a higher standard error, which coincides with the majority of the results presented in literature $(24,25)$. However, it is important to mention that genetic correlations are estimated parameters for a specific population under particular environmental and genetic conditions, and can therefore present variations between populations (18).

Milk yield (PL) was weakly associated with SCS, contradicting the hypotheses that indicate improving milk yield increases the somatic cell score and susceptibility to mastitis. Additionally, some studies have found correlations similar to those reported in this work, reinforcing the idea that highly productive animals that are resistant to mastitis can be achieved through genetic improvement $(19,25)$.

Finally, the estimated phenotypic correlations were generally weak, which coincides with some reports in literature $(22,25)$. However, the values of these correlations are very variable, according to the environment where they were estimated, so that it is common to find higher values in highly controlled production conditions (17). Greater values were obtained for association among the fat percentage $(P G)$ and protein percentage (PP) $(0.48$ and 0.25$)$ for Holstein and Jersey, respectively, which reflects the environmental important on the phenotypic expression of a trait, due to the genetic correlation being high, is diluted by the environment. The results obtained in this investigation agree with those found by other authors for dairy cattle $(19,25)$. It is important to highlight that the phenotypic correlations are generally low, due to the influence of multiple environmental factors and in the majority of the cases the genetic correlations are superior to phenotypic correlations. To conclude, we highlight the importance of developing research studies that can orient genetic improvement programs under tropical conditions in order to obtain selection indexes that include more than one trait.
Las demás correlaciones genéticas fueron muy bajas (menores de 0.1) y con alto error estándar, lo que coincide con la mayoría de resultados presentes en la literatura $(24,25)$. Sin embargo, es importante mencionar que las correlaciones genéticas son parámetros estimados de una población específica bajo condiciones ambientales y genéticas particulares, y por tanto puede presentar variaciones entre poblaciones (18).

La producción de leche (PL) se encontró asociada de manera débil con SCS, contradiciendo los postulados que indican que el mejoramiento en la producción de leche conlleva al aumento en el conteo de células somáticas y la susceptibilidad a mastitis. Adicionalmente, algunos estudios han encontrado correlaciones similares a las reportadas en este trabajo, fortaleciendo la idea que se pueden obtener animales altamente productivos y resistentes a mastitis por medio de mejoramiento genético $(19,25)$.

Finalmente, las correlaciones fenotípicas estimadas entre las diferentes características evaluadas por lo general fueron débiles, lo cual coincide con algunos reportes de la literatura $(22,25)$. Sin embargo, los valores de éstas correlaciones son muy variables de acuerdo al ambiente donde son estimadas, por lo que es común obtener valores más altos en condiciones de producción altamente controladas (17). Los mayores valores fueron obtenidos para la asociación entre el porcentaje de grasa (PG) y el porcentaje de proteína (PP) (0.48 y 0.25$)$ para Holstein y Jersey, respectivamente, lo cual refleja la importancia ambiental sobre la expresión fenotípica de una característica, debido a que la correlación genética siendo alta, es diluida por el ambiente. Los resultados obtenidos en esta investigación concuerdan con los reportes encontrados por otros autores en ganado lechero $(19,25)$. Es importante resaltar que las correlaciones fenotípicas por lo general son bajas, debido a la influencia de múltiples factores ambientales y en la mayoría de los casos las correlaciones genéticas son superiores a las correlaciones fenotípicas. Para concluir, cabe resaltar la importancia de desarrollar trabajos de investigación que permitan orientar los programas de mejoramiento genético en condiciones tropicales con el fin de obtener índices de selección que incluyan más de una característica.

\section{REFERENCIAS}

1. Echeverri J. Evaluación genética de toros para características de importancia económica en la industria lechera. [Tesis Doctoral]. Medellín: Facultad de Ciencias Agrarias, Universidad de Antioquia; 2011.
2. Ruales FR, Manrique C, Cerón ME. Fundamentos en mejoramiento animal. Medellín: L Vieco e Hijas Ltda; 2007. 
3. Echeverri JJ, Quijano JH. Estimación de la heredebilidad y repetibilidad para el porcentaje proteína y grasa de la leche en una población de ganado Holstein del departamento de Antioquia, Colombia. Rev Fac Nac Agron 2009; 62(Supl 1):77 -78.

4. Miglior F, Muir BL, Van Doormaal BJ. Selection indices in Holstein cattle of various countries. J Dairy Sci 2005; 88(3):12551263.

5. Bradley A, Green M. Use and interpretation of somatic cell count data in dairy cows. In practice $2005 ; 27(6): 310-315$.

6. Seegers H, Fourichon C, Beaudeau F. Production effects related to mastitis and mastitis economics in dairy cattle herds. Vet Res 2003; 34(4):475-491

7. Echeverri J, Lopez A, Parra J. Control 1: Manejo y control de producción para hatos lecheros. [Programa de ordenador]. versión 1. Medellín: Editorial Universidad Nacional de Colombia; 2010.

8. SAS Institute Inc. SAS/STAT User's Guide: Version 9. 5th edition. Cary, North Carolina, USA: SAS Institute Inc; 2003.

9. Boldman KG, Kriese LA, Van Vleck LD, Van Tassell CP, Kachman SD. A manual for use of MTDFREML: A set of programs to obtain estimates of variances and covariances [Draft]. Washington (DC): ARS, USDA. 1995.

10. Martínez C, Manrique C, Elzo M. La evaluación genética de vacunos: una percepción histórica. Rev Colomb Cienc Pecu 2012; 25:293-311.

11. Arboleda E, Elzo M, Hurtado-Lugo N, Vergara O, Cerón-Muñoz M. Modelación aplicada a las ciencias animales: II Evaluaciones genéticas. Medellín: Biogénesis Fondo Editorial; 2012.

12. Abe H, Masuda $Y$, Suzuki M. Relationships between reproductive traits of heifers and cows and yield traits for Holsteins in Japan. J Dairy Sci 2009; 92:4055-4062.

13. Makgahlela ML, Banga CB, Norris D, Dzama K, Ng'ambi JW. Genetic correlations between female fertility and production traits in South African Holstein cattle. S Afr Anim Sci 2007; 37(3):180-188.

14. Koivula M, Negussie E, Mäntysaari EA. Genetic parameters for test-day somatic cell count at different lactation stages of Finnish dairy cattle. Livest Sci 2004; 90: 145-157.
15. Mostert BE, Banga C, Groeneveld E, Kanfer $\mathrm{FHJ}$. Breeding value estimation for somatic cell score in South African dairy cattle. S Afr Anim Sci 2004; 34(2):32-34.

16. König S, Chongkasikit N, Langholz HJ. Estimation of variance components for production and fertility traits in Northern Thai dairy cattle to define optimal breeding strategies. Arch Tierz 2005; 48(3):233-246.

17. Toghiani S. Genetic relationships between production traits and reproductive performance in Holstein dairy cows. Arch Tierz 2012; 55(5):458-468.

18. Pereira JC. Melhoramento genético aplicado à produção Animal. $5^{a}$ ed. Belo Horizonte: FEPMVZ Editora; 2008.

19. VanRaden PM, Sanders AH, Tooker ME, Miller $\mathrm{RH}$, Norman HD, Kuhn MT, et al. Development of a national genetic evaluation for cow fertility. J Dairy Sci 2004; 87:2285-2292.

20. Galeano AP, Manrique C. Estimación de parámetros genéticos para características productivas y reproductivas en los sistemas doble propósito del trópico bajo colombiano. Rev Med Vet Zoot 2010; 57:119-131.

21. Dal Zotto R, De Marchi M, Dalvit C, Cassandro M, Gallo L, Carnier P, et al. Heritabilities and genetic correlations of body condition score and calving interval with yield, somatic cell score, and linear type traits in brown Swiss cattle. J Dairy Sci 2007; 90:5737-5743.

22. Kadarmideen HN, Thompson R, Coffey MP, Kossaibati MA. Genetic parameters and evaluations from single- and multiple-trait analysis of dairy cow fertility and milk production. Livest Sci 2003; 81:183-195.

23. Echeverri JJ, Quijano JH. Estimación de las correlaciones genéticas y ambientales entre el porcentaje de proteína y grasa de la leche con algunas características de importancia lechera. Rev Fac Nac Agron 2009; 62(Supl 1):78-79.

24. Carlén $E$, Strandberg $E$, Roth A. Genetic Parameters for Clinical Mastitis, Somatic Cell Score, and Production in the First Three Lactations of Swedish Holstein Cows. J Dairy Sci 2009; 87:3062-3070.

25. Pantelic V, Petrovic MM, Stevica Aleksic, Ostojic D, Sretenovic L, Nuvakovic Z. Genetic correlations of productive and reproductive traits of Simmental cows in Republic of Serbia. Arch Zootech 2008; 11(4):73-78. 